
COVID-19: perspectivas desde una universidad en China

\title{
Emergency remote teaching of English as a foreign language during COVID-19: Perspectives from a university in China
}

Min Huang.

Faculty of Education, Brock University, St Catharines, Canada. mhuang7@outlook.com

Yahui Shi. Department of Foreign Language, Cangzhou Normal University, Cangzhou, China. 183055749@qq.com

Xiaoqiong Yang. Department of Foreign Language, Minjiang University, Fuzhou, China. tracyyang329@gmail.com

\section{RESUMEN.}

Dadas las circunstancias de la pandemia mundial, las universidades de China y de todo el mundo han suspendido las clases presenciales (F2F) y han pasado a la enseñanza remota de emergencia (ERT). Los estudiantes universitarios en China han sido los primeros en pasar por el ERT de todo el semestre, incluido el inglés universitario, un curso de idioma obligatorio para casi todos los estudiantes de primer y segundo año de especializaciones no inglesas. Este artículo adoptó un diseño de métodos mixtos, una encuesta seguida de un método visual cualitativo, recopiló datos sobre la experiencia de los estudiantes sobre ERT de inglés universitario y presentó una investigación sobre el proceso interactivo detallado de las clases. El análisis de datos sobre el compromiso de los alumnos y los comentarios de los alumnos proporcionaron un resumen de los hilos clave de las clases de ERT. Este estudio demostró que los estudiantes tenían una orientación de metas extrínseca, que no difería de su experiencia de aprendizaje cara a cara. ERT otorgó a los estudiantes más oportunidades de interacción con su instructor y compañeros, mientras que la colaboración entre los estudiantes fue limitada. Los resultados de la investigación se pueden conectar con el tejido más amplio de la enseñanza de idiomas global en un contexto de crisis, proporcionar lecciones empíricas a los educadores y ayudar a los instructores con su futura toma de decisiones sobre actividades apoyadas por la tecnología.

\section{PALABRAS CLAVE.}

Enseñanza remota de emergencia; aprender en línea, Inglés como lengua extranjera, COVID-19, compromiso.

\section{ABSTRACT.}

Given the circumstances of the global pandemic, universities around China and across the globe have suspended face to face (F2F) classes and transitioned to emergency remote teaching (ERT). University students in China have been the first to go through the whole

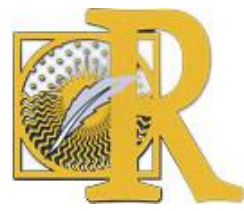


semester's ERT including College English, a compulsory language course for almost all the first- and second-year students of non-English majors. This article adopted a mixed-methods design, a survey followed by a qualitative visual method, gathered data on students' experience about ERT of College English and presented an investigation into detailed interactive process of the classes. The data analysis on the learners' engagement and the feedback from the learners provided a summary of the key threads of ERT classes. This study demonstrated that students held an extrinsic goal orientation, which did not differ from their face-to-face learning experience. ERT granted students more opportunities for interaction with their instructor and peers, while collaboration among students were limited. The research results can be connected to the larger fabric of global language teaching in crisis context, provide empirical lessons to educators, and help instructors with their future decision-making about technology-supported activities.

\section{KEY WORDS.}

Emergency remote teaching, online learning, English as a foreign language, COVID-19, engagement.

\section{Introduction.}

Due to the outbreak of COIVD-19, approximately $90 \%$ of university students, more than 1.5 billion learners of all stages, have been affected by schools and universities' closures globally (Bozkurt \& Sharma, 2020). In China, the first country that experienced the outbreak of COVID -19 in January 2020, the government launched the policy of "suspending classes without stop learning" (Zhang et al., 2020) to reply to the lockdown of schools. This policy aims to support the transfer to online teaching by providing rich and high-quality instructional materials and resources. To enhance the practice of ERT, the government carried out approaches such as "integrating national resources and planning at the top-level", "training teachers", and "enabling local authorities and schools to carry out online teaching in line with local conditions" (W. Zhang et al., 2020, p. 2). Under the guideline of this policy, most schools and universities have undertaken ERT since the Spring semester of 2020 in February, running 24000 online courses over 22 platforms (L. Sun et al., 2020) with more than 100 million students registered in the online education (Wang \& Zhao, 2020).

Among all the universities' subjects, English is an essential course that students take since elementary school or even kindergarten until university. China has been a country with the most English language learners globally, taking about half of English learners all around the world (N. Liu et al., 2016). College English is a compulsory course for university students for non-English major freshmen and sophomores (Ministry of Education, 2007). Students take this course for the first two years of post-secondary study and are required to take College English Test 4 (CET4) by the end of the second year (Liu \& Zhang, 2013). Students have multiple opportunities to take the test and need to obtain a CET4 certificate for graduation.

The decision of distance teaching during the COVID pandemic enables the flexibility of time and location for teachers and students. However, this type of education is distinctive from high-quality online learning because the faulty may not get sufficient online teaching training to parallel standard online courses. In typical online classes, student-student, student-content,

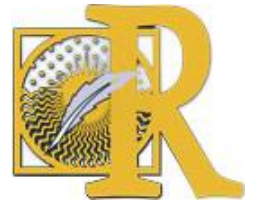


and student-teacher interactions are among the most critical features of technology-based learning (Eom et al., 2006; Kuo et al., 2014). Careful design of curriculum and class activities involving social interactions support learning productivity. While ERT is a temporary solution for universities, it is equally important to consider how students are engaged in the process. The effects of the implementation of ERT of English as a foreign language learning in universities and students' engagement in online education have been a critical concern and are worth investigating. Thus, the purpose of this study is to investigate the effects of ERT on College English students and students' perceptions of online learning.

ERT is "a temporary shift of instructional delivery to an alternate delivery mode due to crisis circumstances"(Hodges et al., 2020, p. 6). This teaching approach, differing from normal online courses, is an alternative of instructional delivery of teaching materials, content, and activities that are planned to be delivered physically, occurring only in time of catastrophes and disasters in the digital age (Bozkurt \& Sharma, 2020; Mohmmed et al., 2020).

Research studies have explored the potential influence of ERT on students' academic achievements and major issues of implementing ERT. A research study investigated the effects of the pandemic on grade 12 students' performance in Zambia (Sintema, 2020). Due to the lack of facilities for remote learning, students had difficulties in connecting and interacting with teachers or peers. In a collective autoethnography from post-secondary students (Peters et al., 2020), researchers indicated that some teachers and students could accept online education immediately despite the emergent switch to online teaching. Zhang (2020) discussed possible problems in the face of ERT in China. The network was unstable and insufficient in some areas; the overload of teaching platforms caused crashes; the teachers applied the offline teaching content and resources directly to the online teaching with minor adaptations. Pace et al. (2020) put forward suggestions for teachers. For example, teachers can enhance students' learning outcomes by developing rapport with students, such as answering students' questions timely, providing immediate feedback, and engaging them in online discussions. Similarly, Zayapragassarazan (2020) put forward flexible learning strategies for enhancing student engagement during the crisis. They suggested a learnercentered approach by which students are provided with flexible learning choices. Regarding higher education in China, researchers also provided instructional strategies for online teaching. Bao (2020), based on the observations of online teaching during the ERT, put forward suggestions to achieve the transition to online learning smoothly: making emergency plans in advance, dividing content into smaller sections, slowing down the speech of voice to help students capture, working with teaching assistants who provide supports for activities, and so forth. A survey study of students' insights into online education in a university in China indicated that students presented low focus and restraint, implying a need to improve their concentration and self-management skills (L. Sun et al., 2020).

Despite the existing literature about the influence of ERT on academic achievements and students' insights into online learning, there has been limited empirical research investigating Chinese higher education College English learners' experiences of engagement when using online platforms for learning in a university in China during the COVID-19 pandemic.

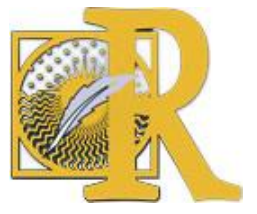

Fecha de recepción: 07-10-2020 Fecha de aceptación: 25-11-2020

Huang, M., Shi, Y. \& Yang, X. (2021). Enseñanza remota de emergencia del inglés como lengua extranjera

durante el COVID-19: perspectivas desde una universidad en China

International Journal of Educational Research and Innovation (IJERI), 15, 400-418

ISSN: 2386-4303 DOI https://doi.org/10.46661/ijeri.5351 


\section{Material and methods.}

This study adopted an explanatory mixed method (Check \& Schutt, 2012; Creswell, 2012) with a quantitative descriptive approach(Berends, 2006; Creswell, 2012), followed by a qualitative visual method (Guillemin \& Drew, 2010; Pink, 2013). A total number of 101 students from a university in China participated in the online survey with $22.77 \%$ male students and $77.23 \%$ female students. Their average age was 20.00 . The participants were all sophomores majoring in Business Administration (1.98\%), Economics (5.94\%), Arts (32.67\%), Education (14.85\%), Chemistry (16.83\%), Mathematics (3.96\%), and Biology (23.76\%). Five students voluntarily participated in the subsequent visual method. The five students were all female and were given pseudonyms in the interviews.

\subsection{RET status.}

In the research site, the university in China, instructors of the College English course embarked on online teaching since the mid of February 2020 using platforms such as Rain Classroom, Tencent Classroom, Tencent Meeting, and Xuexitong. Rain Classroom is a learning platform loaded on a social medium, WeChat, initially designed for face-to-face (F2F) classes where students can preview and review class materials and submit answers on mobile devices (X. Li \& Song, 2018). Similarly, Xuexitong is also a learning platform loaded on WeChat and mainly used on mobile devices, particularly cellphones. Tencent Classroom is an online education platform that allows instructors to develop courses and students to subscribe. Tencent Meeting is a video conferencing tool, similar to Zoom, supporting sharing, collaboration, and text messaging.

\subsection{Survey.}

The online questionnaire was given to students as feedback for the activities. The survey used to explore students' online learning engagement was the Motivated Strategies of Learning Questionnaire (Fredricks \& McColskey, 2012; Pintrich et al., 1991) designed to measure undergraduate students' motivation learning strategies in a course-level. We used 25 questions from the survey that measures four components of task value, metacognitive selfregulation, effort regulation, and peer learning. These questions were Likert scales from strongly agree to strongly disagree. We also planned questions for students' preference of devices and platforms and one open question for students' comments. The numerical data were put into a quantitative analysis software of SPSS for the participants' demographic information and a descriptive analysis of the survey questions. The answers to the openended questions were coded and grouped into themes.

\subsection{Visual Method.}

A photo-production visual method requires participants to take photographs and narrate the experiences (Guillemin \& Drew, 2010) based on specific activities or scenarios revealed in the photographs (Pink, 2013). Students were encouraged to use their cellphones to take pictures of the instructor's online instruction and activities during class time. Five students who took pictures were recruited randomly from the survey participants to discuss in the subsequent

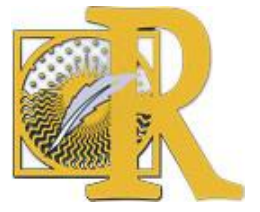


individual interviews. In the online interviews, students displayed photos while explaining the content of pictures, reasons for taking them, and perceptions and expectations for mobile learning. The pictures were categorized into groups according to the content with a particular focus on the components of the pictures and the relationship to the research question (Rose, 2012). Meanwhile, the transcripts were coded and grouped into a prior themes determined by the theoretical framework and emergent themes generated from the interviews and explained the research questions.

\section{Results.}

\subsection{Results from survey.}

The survey results showed that most of the students preferred to use smartphones $(73.27 \%)$ followed by laptops (22.77\%; see Table 1) when learning English online. This research result is parallel with the research of undergraduate students' usage of devices that smartphones and laptops were the dominating devices (Gürleyik \& Akdemir, 2018; Saidouni \& Bahloul, 2016). The preference of smartphones for language learning among Chinese learners may be due to the higher owing rate of smartphones over laptops (Zhang \& Zuo, 2019). Regarding the four online learning platforms, half of the students (54.46\%) presented their preferences of using Tencent Classroom. In contrast, $35.64 \%$ of the students preferred Rain Classroom (see Table 2).

Table 1. The device students use for College English learning.

\begin{tabular}{ll}
\hline Choice & Response \\
\hline Smartphone & $73.27 \%$ \\
Tablet & $2.97 \%$ \\
Desktop & $0.99 \%$ \\
Laptop & $22.77 \%$ \\
Other & $0 \%$ \\
Total number & 101 \\
\hline
\end{tabular}

Table 2. Students' preferences for online learning platforms.

\begin{tabular}{ll}
\hline Choice & Response \\
\hline Rain Classroom & $35.64 \%$ \\
Tencent Classroom & $54.46 \%$ \\
Tencent Meeting & $6.93 \%$ \\
Xuexitong & $0.99 \%$ \\
Other & $1.98 \%$ \\
Total number & 101 \\
\hline
\end{tabular}


The five scales of student experience of online learning (see Table 3) showed that students recognized the value of the tasks in this course and perceived the importance of College English learning $(M=5.28, S D=1.26)$. They recognized the significance of understanding the subject matter $(M=5.48, S D=1.14)$ and course material $(M=5.39, S D=1.26)$ of this course. This result is in accordance with the significance of learning this compulsory course. However, students' self-regulation $(M=4.76, \mathrm{SD}=1.47)$ and effort regulation $(M=4.75, \mathrm{SD}=1.63)$ were lower compared to task value $(M=5.28, S D=1.26)$. This phenomenon can be explained by students' lack of motivational engagement in the learning process as reported in existing research (Q. Li, 2016; Z. Zhang et al., 2015; Zhou, 2012). Also, as indicated in a previous study, in online classes, students' self-management skills were comparatively lower than those in regular F2F classes (Bao, 2020). During the online learning, students indicated some peer learning experiences $(M=4.60, S D=1.56)$, including explaining materials to classmates, discussing materials with others, and working in groups with peers.

Table 3. Students' engagement in online learning.

\begin{tabular}{|c|c|c|}
\hline Scales & $\begin{array}{l}\text { Mean } \\
(\mathrm{M})\end{array}$ & SD \\
\hline Task Value & 5.28 & 1.26 \\
\hline $\begin{array}{l}\text { I think I will be able to use what I learned in this course } \\
\text { in other courses. }\end{array}$ & 5.16 & 1.31 \\
\hline $\begin{array}{l}\text { It is important for me to learn the course material in } \\
\text { this class. }\end{array}$ & 5.39 & 1.26 \\
\hline I'm very interested in the content area of this course. & 5.23 & 1.29 \\
\hline $\begin{array}{l}\text { I think the course material in this class is useful for me } \\
\text { to learn. }\end{array}$ & 5.32 & 1.26 \\
\hline I like this subject matter of this course. & 5.14 & 1.30 \\
\hline $\begin{array}{l}\text { Understanding the subject matter of this course is } \\
\text { very important for me. }\end{array}$ & 5.48 & 1.14 \\
\hline Metacognitive self-regulation & 4.76 & 1.47 \\
\hline $\begin{array}{l}\text { During class time I often miss important points } \\
\text { because I'm thinking of other things. }\end{array}$ & $\begin{array}{c}3.62 \\
\left(4.38^{1}\right)\end{array}$ & 1.77 \\
\hline $\begin{array}{l}\text { When reading for this course, I make up questions to } \\
\text { help focus my reading. }\end{array}$ & 4.69 & 1.45 \\
\hline $\begin{array}{l}\text { When I become confused about something I'm } \\
\text { reading for this class, I go back and try to figure it out. }\end{array}$ & 5.07 & 1.39 \\
\hline $\begin{array}{l}\text { If course materials are difficult to understand, I } \\
\text { change the way I read the material. }\end{array}$ & 5.01 & 1.32 \\
\hline $\begin{array}{l}\text { Before I studied new course material thoroughly, I } \\
\text { often skim it to see how it is organized. }\end{array}$ & 4.92 & 1.43 \\
\hline $\begin{array}{l}\text { I ask myself questions to make sure I understand the } \\
\text { material I have been studying in this course. }\end{array}$ & 4.71 & 1.46 \\
\hline
\end{tabular}


I try to change the way I study in order to fit the course requirements and instructors teaching styles.

I often find that I have been reading for class but I don't know what it was all about.

I try to think through a topic and decide what I'm supposed to learn from it rather than just reading it over when studying.

When studying for this course I tried to determine which concepts I don't understand well.

When I study for this course, I set goals for myself in order to direct my activities in each study period.

If I get confused taking notes in class I make sure I sort it out afterwards.

\section{Effort regulation}

I often feel so lazy or bored when I study for this class that I quit before I finish what I planned to do.

I work hard to do well in this class even if I don't like what we are doing.

When coursework is difficult, I give up or only study the easy parts.

Even when course materials are dull and uninteresting, I managed to keep working until I finish.

$$
\text { Peer learning }
$$

When studying for this course I often try to explain the material to a classmate or a friend.

While studying for the scores I often set aside time to discuss the course material with a group of students from the class.

I try to work with other students from this class to complete the course assignments.
5.06

1.38

4.50

1.49

(3.50)

4.98

1.31

4.91

1.25

4.88

1.24

4.96

1.37

4.75

1.63

3.38

1.93

(4.62)

5.09

1.33

3.65

1.76

(4.35)

4.96

1.32

4.60

1.53

4.65

1.48

4.40

1.59

4.75

1.51

From the open-ended answers, students provide explanations for the rating of specific scales. Students acknowledged the value of this online learning experiences mainly because of the flexibility of learning time and location. Students could schedule learning time and place for their comfort and make learning more convenient. The online course made more use of online resources that broadened and deepened students learning scope. Students' overall perceptions include the following comments:

I think the online teaching approach is excellent because students can have more choices of obtaining knowledge.

This course is crucial, I think, so that I need to put more effort in it.

Overall it is good. The teacher explained nicely, and I got more understanding of the knowledge.

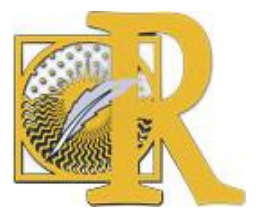

Fecha de recepción: 07-10-2020 Fecha de aceptación: 25-11-2020

Huang, M., Shi, Y. \& Yang, X. (2021). Enseñanza remota de emergencia del inglés como lengua extranjera

durante el COVID-19: perspectivas desde una universidad en China

International Journal of Educational Research and Innovation (IJERI), 15, 400-418

ISSN: 2386-4303 DOI https://doi.org/10.46661/ijeri.5351 
I enjoy this course. Though sometimes it is hard to understand the content, I think English is very useful. So, I hope I can learn it well.

College English is a very challenging yet meaningful course. We will inevitably use English in our life. Learning English well is necessary.

\subsection{Results from visual methods.}

\subsubsection{Extrinsic motivation.}

Students' participation in this online English learning was mainly driven by extrinsic motivation. Because of the upcoming CET4, students looked forward to online activities that could train their abilities to pass the test. This result is in alignment with previous research (Sang, 2017; Zhang \& Zuo, 2019; Z. Zhang et al., 2015) on English learner motivation in China that undergraduate non-English majors learn English with an instrumental goal orientation, such as increasing marks for quizzes and passing examinations. Figure 1 presented a student's score and time of finishing an in-class task, compared with the average score and time of the class on the platform of Rain Classroom. Students' engagement in the course could be examined by those tasks that tested students' concentration on learning. Students submitted answers, which were calculated by the platform automatically, indicating students' participation in this class. This platform can present a statistical result on the instructor's side. The instructor gave students direct feedback based on the answers and suggested those who did not submit answers to pay attention to the class. The benefits of direct feedback from the instructor was similar with previous research about instructor feedback that it enabled learners to receive information about their learning process and outcomes, thus directing learning efforts (Eom et al., 2006).

Figure 1. The result of a student's answers

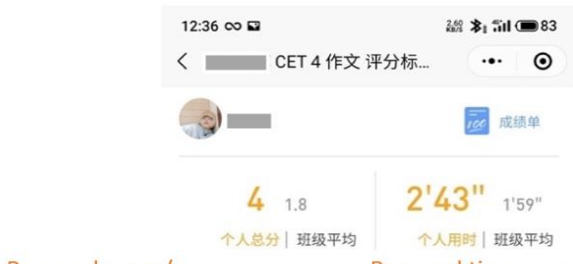

Personal score/ average score Personal time spent/ average time spent
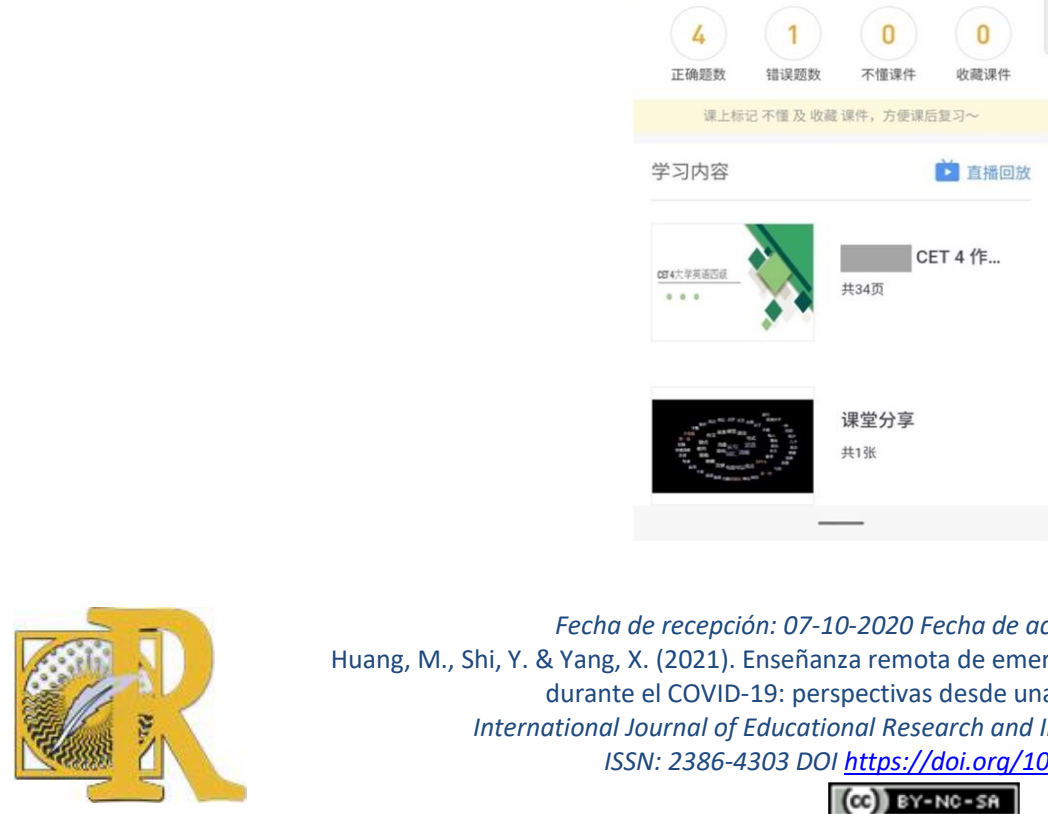

Fecha de recepción: 07-10-2020 Fecha de aceptación: 25-11-2020 
Students indicated that their motivation to learn College English online was to pass CET4 and that materials about CET4 provided by instructors were perceived valuable. This is evident in the responses of several participants:

My motivation to learn English in this course is to pass CET4 because I have not taken this exam. My instructor will talk about some CET4 questions and strategies to answer them. I found it very meaningful, so I learned this course on my own initiative. And the reason is because of CET4. ( $\mathrm{J}$, Female)

I feel that I learn English, no matter online or in F2F class, to get some certificates while I'm still a student. It's for exams. If l'm capable enough, l'll consider pursuing a master's degree. (B, Female)

Among the five students participating in the interviews, only one indicated implicit goal orientation in learning English. She took careful notes of the lecture because she believed that the notes would help her preview and review. She indicated her initiatives in finishing tasks because of her intrinsic interest in it and the inner desire to acquire the language skills.

\subsubsection{Distinctive functions.}

Students perceived that most of the procedures of online learning were similar to F2F learning. In a F2F class, instructors handed out paper questions for students to answer; while in the online class, students answered the same questions on the platform. Yet, there are some functions distinctive from regular classes. Bullet screen is the most commonly mentioned functions by those students (Figure 2). When answering questions on Rain Classroom, students typed comments that appeared on the screen and moved from the bottom to the top. They used this function for answering/asking questions, practicing vocabularies by typing them for memorization, having conversations, and taking attendance. Participants explained this in their comments as follows:

Our instructor uses bullet screens to check our learning status, and we also use it for communication. Since students can type a bullet screen anytime during the class, we use it to have conversations. We can put forward our thoughts regarding the content of the lecture. For example, our instructor asked us the meaning of a word or how to spell a word; students usually respond by typing bullet screens. Many of us are typically very active in answering this type of question. (B, Female)

We use bullet screens to answer questions. Our instructor also called students' names of those who don't imitatively answer questions. This is a useful way for the instructor to manage our responses. (L, Female) 
Figure 2. A screenshot of Bullet screens on Rain Classroom

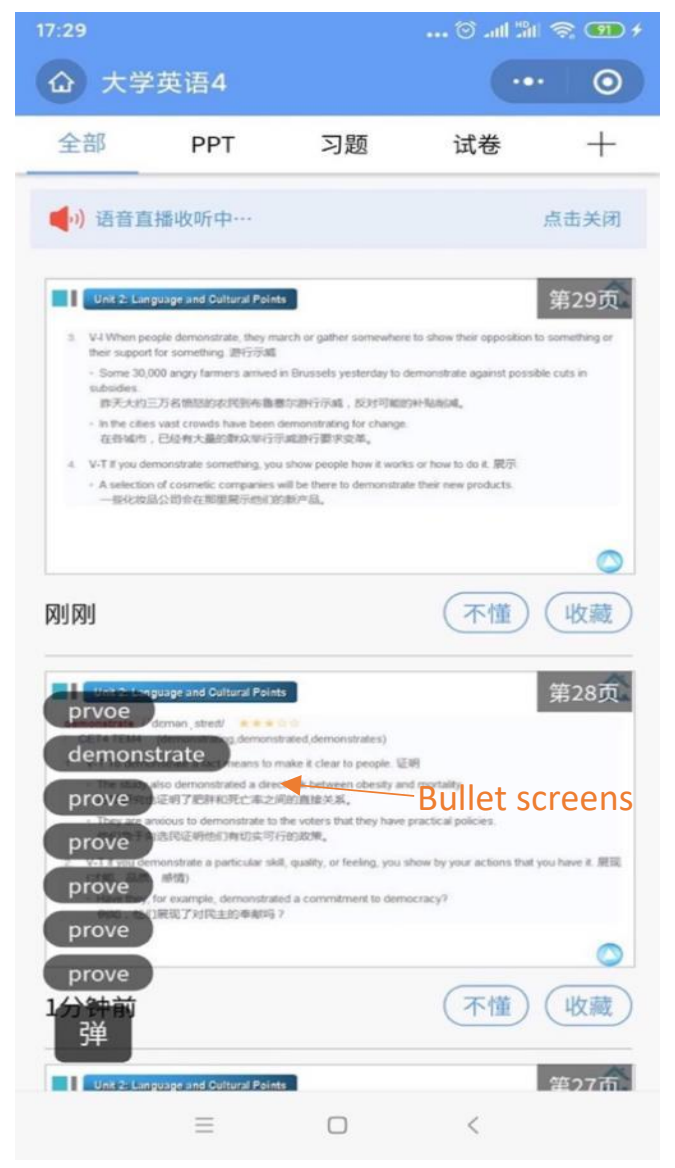

According to the participants, using bullet screens for repetition, vocabulary memorization, and icebreaker activities is also a function they enjoyed because of the active learning atmosphere bullet screens produced.

The atmosphere of this class usually is excellent because we can see lots of bullet screens flying. Sometimes, we encountered an unfamiliar word, and we type it in the bullet screen for practice. Occasionally, we find the word quite familiar but not sure how to spell; we also type it to ensure its spelling and make more impression of it... we also use it for icebreaker activates in our class. Our instructor may talk about a hot topic at the beginning of the class, and we use bullet screens to chat. It is quite interesting because we all were attracted to this topic and talked about our thoughts. It makes us quite excited so that we could focus on the following content (B, Female).

Students reflected two major ways of interacting with the instructor or classmates. The first way is bullet screens that are typed by students and sent to the screen. Bullet screens can be typed anytime in the online platform of Rain Classroom. Another type of interaction is through

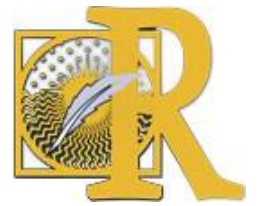

Fecha de recepción: 07-10-2020 Fecha de aceptación: 25-11-2020 
unmuting audio (see Figure 3) in Tencent Classroom. Usually, the instructor asked a question and called a student to be connected through audio, by which the student answered the question or had a short conversation with the instructor.

On Rain Classroom, we use bullet screens to communicate with our instructor, such as answering questions or clarifying questions. In Tencent Classroom, I push the Raise Hand button so that the instructor will see the signal and call my name to have a conversation. (H, Female)

Figure 3. Unmuting status on Tencent Classroom.

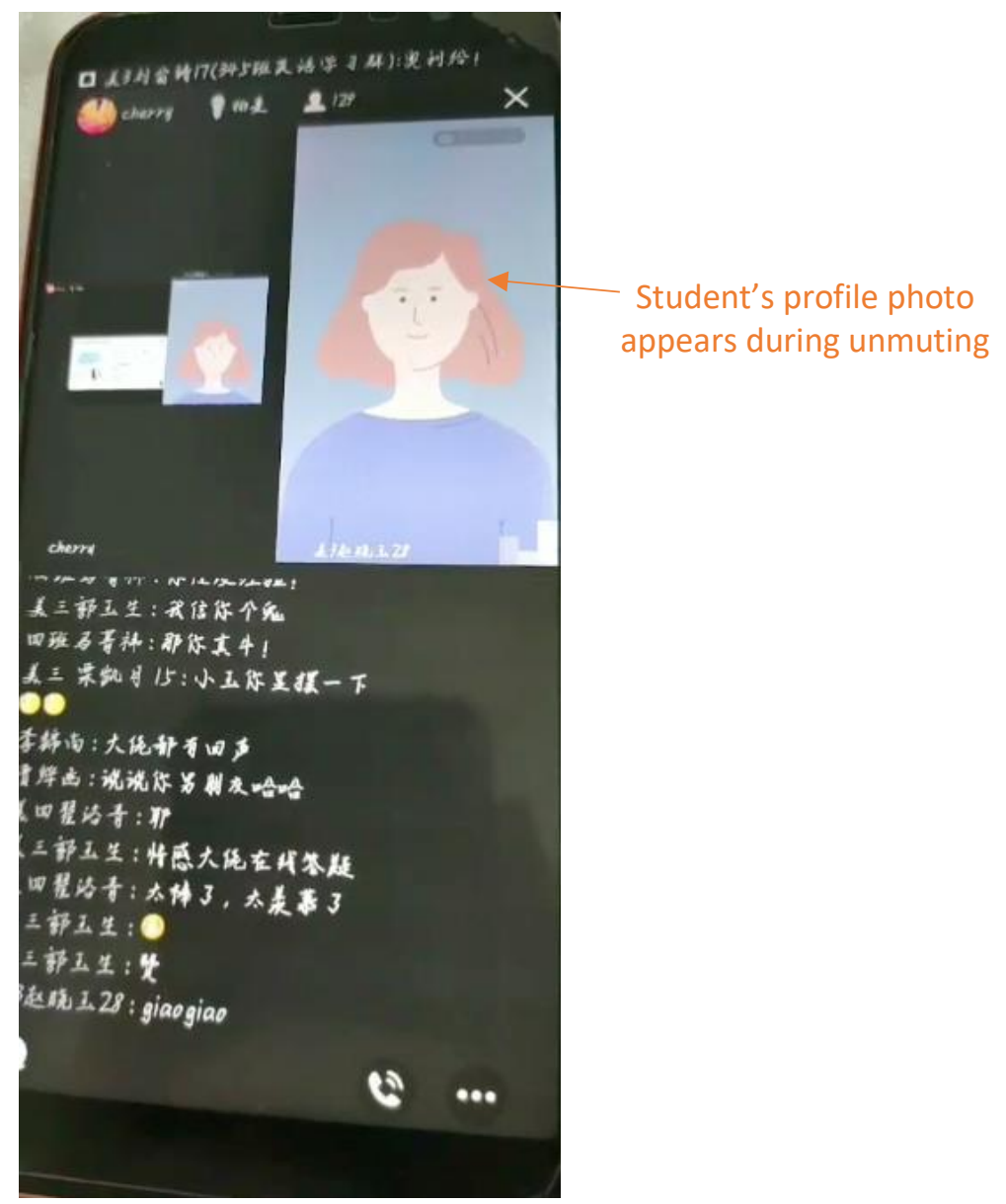

The interaction among peers was mainly based on bullet screens used for students to ask and answer questions. For instance, if students have questions, they usually type bullet screens; other students could respond by providing suggestions or comments using bullet screens. Students had more interactions online because the bullet screens were anonymous for the students, thus keeping confidentiality. Because of the characteristics of Chinese students who prefer to conceal their thoughts in public, this feature helped with hiding students' identities so that they felt more comfortable expressing opinions in public. Students felt less stressed and

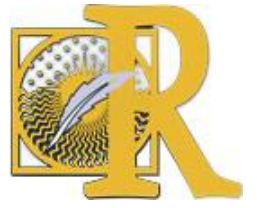

Fecha de recepción: 07-10-2020 Fecha de aceptación: 25-11-2020 


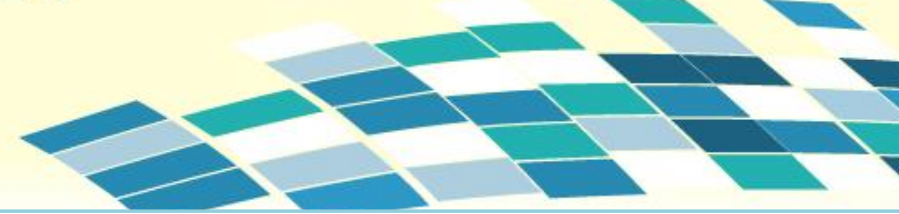

Min Huang, Yahui Shi \& Xiaoqiong Yang. Enseñanza remota de emergencia del inglés como lengua extranjera durante el CoVID-19: perspectivas desde una universidad en China

had multiple choices for interaction, such as typing bullet screens, pushing the Raise Hand button for the instructor's calling, or sending a private message on the platform.

\subsubsection{Choice of devices.}

As indicated in the survey, most of the students preferred to use cellphones. The qualitative result is in alignment with the survey result. Though many students had multiple choices of devices, they chose smartphones for this online course. On the one hand, they highlighted that Rain Classroom was a mobile application designed mainly for cellphones. Logging in from the PC side was not as convenient as on the cellphone side. On the other hand, despite small cellphone screens, students got used to them because of the frequent use of cellphones in daily life. Some of the students thought that they typed faster on cellphones. In Figure 4, the participant indicated that she preferred to use the smartphone because she was accustomed to it for daily use. In her case, using her cellphone for this online course was a priority, while the laptop was a substitute only when the cellphone could not function normally.

Figure 4. A student using a smartphone for learning with a laptop in the back.

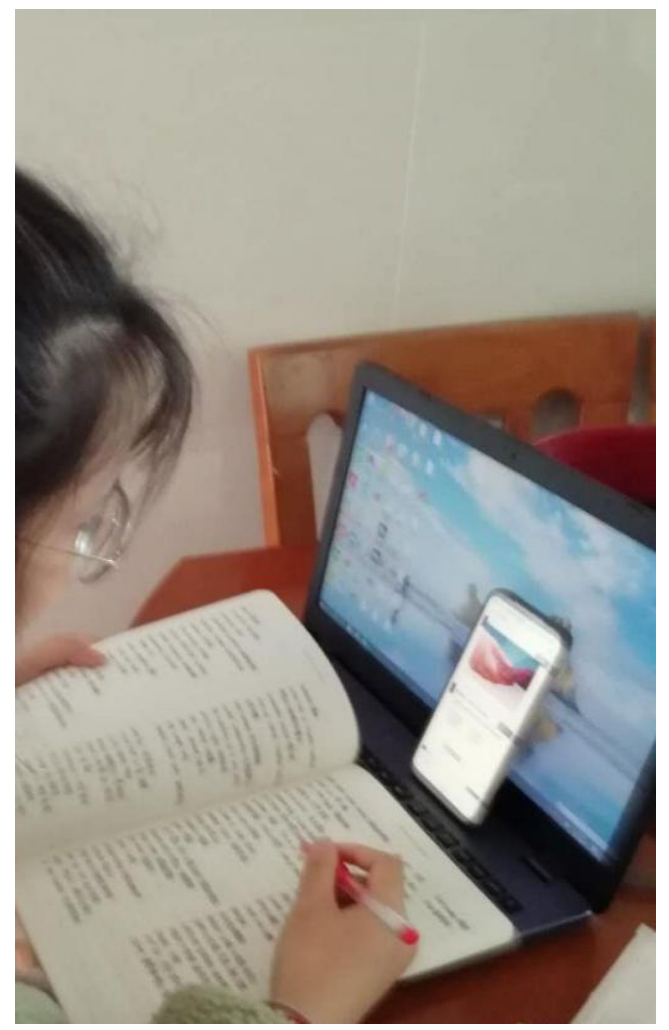

\subsubsection{Drawbacks of online learning.}

Students put forward the following drawbacks that worth educators' attention. (1) Rain Classroom was designed for cellphones and only loaded via a mobile application, WeChat. This platform setting prevented accessibility through laptops, contributing to the low rate of

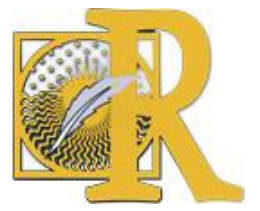

Fecha de recepción: 07-10-2020 Fecha de aceptación: 25-11-2020

Huang, M., Shi, Y. \& Yang, X. (2021). Enseñanza remota de emergencia del inglés como lengua extranjera 
using laptops for learning. (2) The internet connection from time to time was slow and affected the process of online learning. (3) Students indicated that though bullet screens were attractive and helpful, it could not be reviewed on the students' side. (4) The COVID teaching was not systematic or mature. The instructor had to switch between the platforms when the internet was not stable, or the platform was overloaded. (5) Though the instructor can manage the class by using different approaches, such as calling attendance and using online pop quizzes, it was difficult to ensure students' concentration and behaviors.

\subsubsection{Expectations of online learning.}

Game-based activities were expected by some students who hoped to have a more interesting and enjoyable learning environment where all the students can participate. Formal language learning coupled with game-based activities has been demonstrated enjoyable, motivating, and engaging (Berns et al., 2016; Cho \& Castañeda, 2019; Freiermuth, 2017; Kebritchi et al., 2010). Game-based learning has been regarded as a learning strategy that combines entertainment and educational purposes (Berns et al., 2016), thus motivating students to participate in the learning procedure and enhancing knowledge accumulation.

More synchronous voice communications were also expected in online College English classes. Synchronous learning has a positive effect on increasing students' satisfaction and engagement (Northey et al., 2018). Synchronous communications in language classrooms enable students a sense of engagement and opportunities to practice speaking skills.

Because of low self-regulation in the online learning environment, students assumed that setting up a mandatory English learning schedule might help ensure the amount of time committed to English. Compared with F2F classes, instructors have less control over online teaching, the result of which may lead to students skipping the class (Bao, 2020). Therefore, it is vital to design the course more engaging, involving students' participation in the activities.

\section{Discussion.}

In this study, the Students' motivation was mainly extrinsically or instrumentally driven. The motive for learning College English was either based on passing examinations or getting rewards. To enhance students' intrinsic motivation, instructors need to build an enjoyable learning environment in which students can actively participate in activities and be engaged in the class content. Students' positive perceptions towards bullets screens and voice communication suggested their eagerness to be involved in the learning process instead of passively deposit knowledge. In English classes in China, the most widely adopted method is the grammar-translation method, which is emphasized in the instruction of structure and rote memorization (Liu et al., 2016). This transfer to online learning reflects the necessity of employing more student-centered teaching approaches, such as task-based language teaching, communicative language teaching, and game-based teaching that focus on language communication in the learning process.

This study has demonstrated that students in the language classroom shared more moments to interact with the instructor and their peers. Yet, collaboration did not appear on the agenda of the emergency remote teaching in spite of the affordability of online platforms. Ellis (1994) suggests that multiple ways of information exchanges are more efficient than one-way

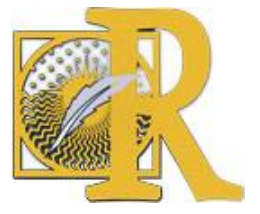

Fecha de recepción: 07-10-2020 Fecha de aceptación: 25-11-2020

Huang, M., Shi, Y. \& Yang, X. (2021). Enseñanza remota de emergencia del inglés como lengua extranjera

durante el COVID-19: perspectivas desde una universidad en China

International Journal of Educational Research and Innovation (IJERI), 15, 400-418

ISSN: 2386-4303 DOI https://doi.org/10.46661/ijeri.5351 
exchange, highlighting the significance of interactional and collaborative communication. Assistance from more knowledgeable others will contribute to individuals' language acquisition by expanding their knowledge scope (Wertsch, 2008). As one of the distinguishing features of progressive education, collaboration should be considered when designing activities. By participating in real-life related tasks involving cooperation among peers, students will benefit from this quality contributing to personal development and teamwork in future careers.

Students' learning experience reflected that the learning content and activities were similar to those in the offline classes. This phenomenon can be explained by the reason that teachers were not fully trained for online teaching approaches. In online learning environments, instructors take the facilitators' role to facilitate, stimulate, and challenge students instead of delivering instructions (Eom et al., 2006). Though online courses had been taken place in universities in China, they were regarded as minor supplements to F2F classes (W. Zhang et al., 2020). Instructors should be provided with more training of online teaching approaches and pedagogies to deliver the instruction. This unpredictable change of education requires educators to be prepared for innovations and revolutions of teaching. This emergency online teaching is a reminder for educators to move out of their comfort zones of teaching philosophies and methods and to welcome pedagogies that fit the social context and accommodate learners' needs.

This research presented pedagogical problems of College English teaching. English education in China is progressing toward learner-centered methodologies and improving learners' English communicative abilities (Liu et al., 2016). However, this study shows that students were still learning English based on a teacher-centered approach with rare opportunities for communication. This phenomenon is parallel with previous research (Z. Sun et al., 2017). The large size setting of college English indicates limited opportunities for students to be engaged for interactions. Despite the options of expression through typing bullet screens, language achievement is a complex mixture that requires the development of speaking, writing, listening, and reading abilities. Possible changes in College English classes can be as follows. A smaller size of learners in each class may benefit more from the classrooms with more time, attention, and scaffolding for individuals' learning needs. Seminars, a teaching approach aiming at learners' participation in discussions and involvement, can also be introduced and integrated into College English classes to enable learners' initiative language interactions.

Last but not least, smartphones were dominant devices among university students in China and this type of mobile devices is suggested to be incorporated into formal online and F2F learning. The utilization of smartphones for formal education meets the requirement of remoulding universities' teaching models by the Ministry of Education (2017) in China. This study showcases smartphones' potentials for language learning purposes beyond stereotypes, e.g., communication and entertainment, of smartphones, thus embracing the possibilities of adopting smartphones for formal in-class use. Kukulska-Hulme and Viberg (2018) emphasized the unique features of mobile-assisted language learning: portability, spontaneity, and interaction. Those advantages of mobile learning have been partially

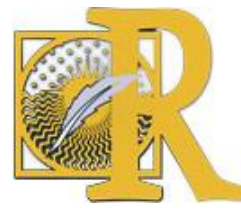

Fecha de recepción: 07-10-2020 Fecha de aceptación: 25-11-2020

Huang, M., Shi, Y. \& Yang, X. (2021). Enseñanza remota de emergencia del inglés como lengua extranjera

durante el COVID-19: perspectivas desde una universidad en China

International Journal of Educational Research and Innovation (IJERI), 15, 400-418

ISSN: 2386-4303 DOI https://doi.org/10.46661/ijeri.5351 
demonstrated in this study. The hybrid format of College English learning, integrating mobile learning into conventional formal classrooms, will benefit from both learning approaches.

\section{Conclusion.}

In summary, this article investigated students' online learning status in College English classes in a university in China during the pandemic of COVID-19. Students' motivation in this emergency remote teaching period was dominantly driven by extrinsic goals, among which passing CET4 was the major rationale of engaging in the class. This result is parallel with previous research about Chinese students' English learning motivation (Sang, 2017; Zhang \& Guo, 2015; Zhang et.al, 2015). Students' extrinsic motivation of learning College English in this virtual classroom did not differ from their participation in the F2F classroom, showcasing the significance of this examination among university students. This, however, also demonstrated that College English, either in the conventional classroom or in the virtual environment, did not motivate students to learn English towards an intrinsic goal orientation. It is suggested that College English instructors design and incorporate activities or tasks that are real-life related and can facilitate students' inner interests in English learning.

This study also uncovered university students' preferences for digital learning devices, the drawbacks of emergency remote teaching approaches, and students' expectations for future classrooms. The research and development of applications on mobile devices are at a tremendous speed. Learners have easy access to multiple learning platforms for formal and informal learning via handful smartphones. Most students choose smartphones for English learning based on the accessibility, flexibility, and convenience of this type of mobile device. Yet, this also revealed the drawbacks of emergency remote teaching. Both instructors and students were not provided with a single, stable online platform that can be accessed at ease by smartphones, computers, or tables. A reliable online learning platform should be provided by the university to ensure seamless joint learning in any emergency. Meanwhile, universities should also take the responsibilities of training instructors of technology-assisted teaching approaches consistent with their pedagogies and instructional content. In future College English classes, game-based learning and collaboration among peers are expected to be integrated. A hybrid learning approach, the blending of F2F learning with the online learning features, such as text-based communication, online answer gathering, statistical results presenting, and instant feedback, is highly recommended in future College English learning.

\section{Limitations and contributions.}

The limitations of this research study are as follows. This study only involved students from the classes that we had easy access to. The sample size was small, making it difficult to ensure a representative distribution of College English learners in the university. For the qualitative section, only female students participated in the study, thus lacking a gender balance and representativeness. The results from this study about one single university may not be generalizable to other universities or learning contexts.

In spite of that, this study contributes to the current educational conditions by suggesting developing technological pedagogical content knowledge for faculty to cope with this pandemic and any crisis. Remote teaching is an optimal substitute for F2F classes during this

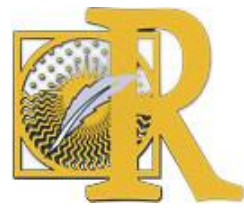

Fecha de recepción: 07-10-2020 Fecha de aceptación: 25-11-2020

Huang, M., Shi, Y. \& Yang, X. (2021). Enseñanza remota de emergencia del inglés como lengua extranjera

durante el COVID-19: perspectivas desde una universidad en China

International Journal of Educational Research and Innovation (IJERI), 15, 400-418

ISSN: 2386-4303 DOI https://doi.org/10.46661/ijeri.5351 
emergency. Yet, it requires instructors' knowledge of technology, pedagogy, content knowledge, and any two factors among them. Instructors are suggested to explore and employ the features of online platforms, resources, and technologies to combine their teaching philosophies and teaching content, thus enhancing the knowledge about teaching with technology. This study, therefore, will strengthen the development of university instructors towards technology-assisted teaching methods.

The return to regular education may take steps gradually instead of a one-step transition. This may require the operation of online courses or hybrid classes continuously. This exploration of students' online learning experiences during the pandemic provides feedback to the instructors who are currently committing remote online teaching. In response, corresponding adjustments can be made to create a more enriching learning environment. As a substitute for F2F education during this crisis, this ERT has urged educators to learn technological and digital teaching approaches. During this period, this practice may change people's teaching and pedagogy methods because they attempted what they had never used and might find the usefulness of mobile technologies. A blend of the features of mobile technologies that people find useful and offline education is suggested to be incorporated in the future F2F classes, creating a more engaging and interactive learning environment.

\section{References}

- Bao, W. (2020). COVID-19 and online teaching in higher education: A case study of Peking University. Human Behavior and Emerging Technologies, 2(2), 113-115. https://doi.org/10.1002/hbe2.191

- Berns, A., Isla-Montes, J.-L., Palomo-Duarte, M., \& Dodero, J.-M. (2016). Motivation, students' needs and learning outcomes: A hybrid game-based app for enhanced language learning. SpringerPlus, 5(1), 1-23. https://doi.org/10.1186/s40064-016-2971-1

- Bozkurt, A., \& Sharma, R. C. (2020). Emergency remote teaching in a time of global crisis due to Coronavirus pandemic. Asian Journal of Distance Education, 15(1), 1-6.

- Cho, M.-H., \& Castañeda, D. A. (2019). Motivational and affective engagement in learning Spanish with a mobile application. System, 81, 90-99. https://doi.org/10.1016/i.system.2019.01.008

- Creswell, J. W. (2012). Educational research: Planning, conducting, and evaluating quantitative and qualitative research (4th ed). Pearson.

- Ellis, R., Tanaka, Y., \& Yamazaki, A. (1994). Classroom interaction, comprehension, and the acquisition of L2 word meanings. Language Learning, 44(3), 449-491. https://doi.org/10.1111/j.1467-1770.1994.tb01114.x

- Eom, S. B., Wen, H. J., \& Ashill, N. (2006). The determinants of students' perceived learning outcomes and satisfaction in university online education: An empirical investigation*. Decision Sciences Journal of Innovative Education, 4(2), 215-235. https://doi.org/10.1111/j.1540-4609.2006.00114.x

- Fredricks, J. A., \& McColskey, W. (2012). The measurement of student engagement: A comparative analysis of various methods and student self-report instruments. In S. L.

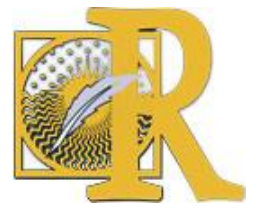

Fecha de recepción: 07-10-2020 Fecha de aceptación: 25-11-2020

Huang, M., Shi, Y. \& Yang, X. (2021). Enseñanza remota de emergencia del inglés como lengua extranjera durante el COVID-19: perspectivas desde una universidad en China

International Journal of Educational Research and Innovation (IJERI), 15, 400-418 ISSN: 2386-4303 DOI https://doi.org/10.46661/ijeri.5351 
Christenson, A. L. Reschly, \& C. Wylie (Eds.), Handbook of Research on Student Engagement (pp. 763-782). Springer US. https://doi.org/10.1007/978-1-4614-2018-7 37

- Freiermuth, M. R. (2017). 'I Found It!' A smartphone GPS treasure-hunting game in a flipped English class. Innovation in Language Learning and Teaching, 11(2), 101-108. https://doi.org/10.1080/17501229.2015.1066793

- Gay, L. R. (2006). Educational research: Competencies for analysis and applications (8th ed.). Pearson Merrill Prentice Hall.

- Guillemin, M., \& Drew, S. (2010). Questions of process in participant-generated visual methodologies. Visual Studies, $\quad$ 25(2), 175-188. https://doi.org/10.1080/1472586X.2010.502676

- Gürleyik, S., \& Akdemir, E. (2018). Guiding curriculum development: Student perceptions for the second language learning in technology-enhanced learning environments. Journal of Education and Training Studies, 6(4), 131-138. https://doi.org/10.11114/jets.v6i4.2994

- Hodges, C., Moore, S., Lockee, B., Trust, T., \& Bond, A. (2020). The difference between emergency remote teaching and online learning. EDUCAUSE Review. Retrieved from: https://er.educause.edu/articles/2020/3/the-difference-between-emergency-remoteteaching-and-online-learning

- Kebritchi, M., Hirumi, A., \& Bai, H. (2010). The effects of modern mathematics computer games on mathematics achievement and class motivation. Computers \& Education, 55(2), 427-443. https://doi.org/10.1016/i.compedu.2010.02.007

- Kukulska-Hulme, A., \& Viberg, O. (2018). Mobile collaborative language learning: State of the art: Mobile collaborative language learning. British Journal of Educational Technology, 49(2), 207-218. https://doi.org/10.1111/bjet.12580

- Kuo, Y.-C., Walker, A. E., Schroder, K. E. E., \& Belland, B. R. (2014). Interaction, internet self-efficacy, and self-regulated learning as predictors of student satisfaction in online education courses. The Internet and Higher Education, 20, 35-50. https://doi.org/10.1016/j.iheduc.2013.10.001

- Li, Q. (2016). Changes in the motivation of Chinese ESL learners: A qualitative investigation. English Language Teaching, 10(1), 112-122. https://doi.org/10.5539/elt.v10n1p112

- Li, X., \& Song, S. (2018). Mobile technology affordance and its social implications: A case of "Rain Classroom." British Journal of Educational Technology, 49(2), 276-291. https://doi.org/10.1111/bjet.12586

- Liu, N., Lin, C.-K., \& Wiley, T. G. (2016). Learner views on English and English language teaching in China. International Multilingual Research Journal, 10(2), 137-157. https://doi.org/10.1080/19313152.2016.1147308

- Mohmmed, A. O., Khidhir, B. A., Nazeer, A., \& Vijayan, V. J. (2020). Emergency remote teaching during Coronavirus pandemic: The current trend and future directive at Middle East College Oman. Innovative Infrastructure Solutions, 5(3), 1-11. https://doi.org/10.1007/s41062-020-00326-7

- Northey, G., Govind, R., Bucic, T., Chylinski, M., Dolan, R., \& Esch, P. van. (2018). The effect of "here and now" learning on student engagement and academic achievement.

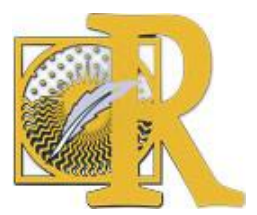


Min Huang, Yahui Shi \& Xiaoqiong Yang. Enseñanza remota de emergencia del inglés como lengua extranjera durante el COVID-19: perspectivas desde una universidad en China
British
Journal of
Educational
Technology,
49(2),
321-333.

https://doi.org/10.1111/bjet.12589

- Pace, C., Pettit, S., \& Barker, K. (2020). Best practices in middle level quaranteaching: Strategies, tips and resources amidst COVID-19. Becoming: Journal of the Georgia Middle School Association, 31(1), 1-13. https://doi.org/10.20429/becoming.2020.310102

- Peters, M. A., Wang, H., Ogunniran, M. O., Huang, Y., Green, B., Chunga, J. O., Quainoo, E. A., Ren, Z., Hollings, S., Mou, C., Khomera, S. W., Zhang, M., Zhou, S., Laimeche, A., Zheng, W., Xu, R., Jackson, L., \& Hayes, S. (2020). China's internationalized higher education during COVID-19: Collective student autoethnography. Postdigital Science and Education. https://doi.org/10.1007/s42438-020-00128-1

- Pink, S. (2013). Doing Visual Ethnography. SAGE.

- Pintrich, P., Smith, D., Garcia, T., \& McKeachie, W. (1991). A manual for the use of the motivated strategies for learning questionaire.pdf. The University of Michigan.

- Reavey, P. (2012). Visual methods in psychology: Using and interpreting images in qualitative research. Routledge.

- Saidouni, K., \& Bahloul, A. (2016). Teachers and students' attitudes towards using mobileassisted language learning in higher education. Arab World English Journal, 3, 123-140.

- Sang, Y. (2017). Investigate the "issues" in Chinese students' English writing and their "reasons": Revisiting the recent evidence in Chinese academia. International Journal of Higher Education, 6(3), 1-11. https://doi.org/10.5430/ijhe.v6n3p1

- Sintema, E. J. (2020). Effect of COVID-19 on the performance of grade 12 students: Implications for STEM education. Eurasia Journal of Mathematics, Science and Technology Education, 16(7), 1-6. https://doi.org/10.29333/ejmste/7893

- Sun, L., Tang, Y., \& Zuo, W. (2020). Coronavirus pushes education online. Nature Materials, 19(6), 687-687. https://doi.org/10.1038/s41563-020-0678-8

- Sun, Z., Lin, C.-H., You, J., Shen, H. jiao, Qi, S., \& Luo, L. (2017). Improving the Englishspeaking skills of young learners through mobile social networking. Computer Assisted Language Learning, 30(3-4), 304-324. https://doi.org/10.1080/09588221.2017.1308384

- Wang, C., \& Zhao, H. (2020). The impact of COVID-19 on anxiety in Chinese university students. Frontiers in Psychology, 11, 1-8. https://doi.org/10.3389/fpsyg.2020.01168

- Wertsch, J. V. (2008). From social interaction to higher psychological processes. Human Development, 51(1), 66-79. https://doi.org/10.1159/000112532

- Zayapragassarazan, Z. (2020). COVID-19: Strategies for online engagement of remote learners. F1000Research 2020, 2 9(246), 1-11. https://doi.org/10.7490/F1000RESEARCH.1117835.1

- Zhang, W., Wang, Y., Yang, L., \& Wang, C. (2020). Suspending classes without stopping learning: China's education emergency management policy in the COVID-19 outbreak. Journal of Risk and Financial Management, 13(3), 1-6. https://doi.org/10.3390/jifm13030055

- Zhang, Y., \& Zuo, L. (2019). College english teaching status and individualized teaching design in the context of mobile learning. International Journal of Emerging Technologies in Learning (IJET), 14(12), 85. https://doi.org/10.3991/ijet.v14i12.10704

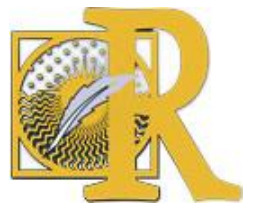

Fecha de recepción: 07-10-2020 Fecha de aceptación: 25-11-2020

Huang, M., Shi, Y. \& Yang, X. (2021). Enseñanza remota de emergencia del inglés como lengua extranjera

durante el COVID-19: perspectivas desde una universidad en China

International Journal of Educational Research and Innovation (IJERI), 15, 400-418

ISSN: 2386-4303 DOI https://doi.org/10.46661/ijeri.5351 
- Zhang, Z., Hu, W., \& Mcnamara, O. (2015). Undergraduate student engagement at a Chinese university: A case study. Educational Assessment, Evaluation and Accountability; Dordrecht, 27(2), 105-127. http://dx.doi.org.proxy.library.brocku.ca/10.1007/s11092-0159213-x

- Zhou, H. (2012). Enhancing non-English majors' EFL motivation through cooperative learning. Procedia Environmental Sciences, 12 , 1317-1323. https://doi.org/10.1016/j.proenv.2012.01.428

1 The number shown in the bracket means a negative and has been subtracted from 8 to represent a positive value. 